УДК 82I.I33.I.O

ББК $83.3(4 Ф$ ра $) 5 \mathrm{I}$
ТЕАТР КАК ДИКТАТ ВЛАСТИ. ПРОБЛЕМА

СВОБОДЫ ДРАМАТИЧЕСКОГО АВТОРА

В КЛАССИЦИСТИЧЕСКУЮ ЭПОХУ

(ПЬЕР КОРНЕЛЬ)

(с) 2020 г. Л.А. Симонова
Московский финансово-юридический универси-
тет, Москва, Россия
Дата поступления статьи: ог ноября 2ОІ9 г.
Дата публикации: 25 декабря 2020 г.
DOI: https://doi.org/Іо.22455/2500-4247-2020-5-4-Іо2-І25

Аннотация: Автор статьи ставит цель пересмотреть традиционные подходы к определению классицизма как внутренне подвижной и неоднородной знаково-смысловой системы. Французский театр XVII в. (здесь на примере трагедийного жанра как доминирующего) определяется в двух ракурсах: социально-политический феномен и авторскими усилиями функционирующая и трансформирующаяся система. Подвижность драматургической практики прослеживается через парадигму взаимосвязи «власти» и «автора». При этом власть рассматривается как в узком смысле (политическом), так и в широком (всякое понуждающее давление, проявляемое на уровне текста), в соответствии с этим автор понимается как пишущий, последовательно вырабатывающий собственные принципы драматического письма, проявляющий себя в тексте через фигуры отдельных персонажей и драматическую структуру в целом. С целью отчетливее показать согласие Корнеля как драматурга с преобладающими тенденциями укрепления сверхсмысла и одновременно его страхующее дистанцирование от него, в статье разбирается принцип построения риторической структуры трагедии «Гораций», в частности, сближение и отталкивание двух дискурсивных позиций - Горация и Сабины.

Ключевые слова: драма, классицизм, трагедия, власть, автор, герой, дискурс.

Информация об авторе: Лариса Алексеевна Симонова - кандидат филологических наук, преподаватель кафедры гуманитарных дисциплин, Московский финансовоюридический университет, ул. Введенского, д. IA, II7342 г. Москва, Россия.

ORCID ID: https://orcid.org/oooo-oooI-70I9-0215

E-mail: mouette37@yandex.ru

Для цитирования: Симонова Л.А. Театр как диктат власти. Проблема свободы драматического автора в классицистическую эпоху (Пьер Корнель) // Studia Litterarum. 2020. T. 5, № 4. C. IO2-I25. https://doi.org/IO.22455/2500-4247-2020-5-4-IO2-I25 


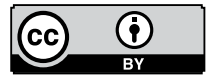

This is an open access article distributed under the Creative Commons Attribution 4.0 International (CC BY 4.0)

\section{THEATER AS A DICTATE OF POWER. THE PROBLEM OF FREEDOM OF THE DRAMATIC AUTHOR IN THE CLASSICAL $\mathrm{EPOCH}$}

(C) 2020. L.A. Simonova

Moscow University of Finance and Law, Moscow, Russia Received: November OI, 2019

Date of publication: December 25, 2020

Abstract: The author of the article aims at revising traditional approaches to the definition of classicism, viewing it as an intrinsically mobile and heterogeneous semantic system. On the example of the tragedy as a dominant genre, it reveals that the French theater of the $I 7^{\text {th }}$ century may be seen from two perspectives: as a social and cultural phenomenon and as a system that functions and transforms itself through the author's efforts. The mobility of this dramatic practice relates to the paradigmatical relationship between the "power" and the "author". The power is understood both in the narrow political and in the wider textual sense (e.g. violence that reveals itself on the textual level). The author is seen as a writing agent who consistently develops her own principles of dramatic writing and discloses herself in the text through the figures of the drama's personas and the structure as a whole. The article seeks to show how Corneille the playwright simultaneously succumbed to the prevailing classical tendencies of his time and tried to distance from them. With this purpose in view, the article examines in detail how the rhetorical structure of the tragedy Horace was built; in particular, this concerns interaction, via attracrion and repulsion, of two different discursive positions represented by Horace and Sabina.

Keywords: drama, classicism, tragedy, power, author, character, discourse.

Information about the author: Larisa A. Simonova, PhD in Philology, Professor, Moscow University of Finance and Law, Vedenskogo St. IA, II7342 Moscow, Russia. ORCID ID: https://orcid.org/oooo-00oI-7019-0215

E-mail: mouette37@yandex.ru

For citation: Simonova L.A. Theater as a Dictate of Power. The Problem of Freedom of the Dramatic Author in the Classical Epoch. Studia Litterarum, 2020, vol. 5, no 4, pp. IO2-I25. (In Russ.) https://doi.org/IO.22455/2500-4247-202O-5-4-IO2-I25 
Включение в поле исследовательского внимания конкретного исторического периода, а именно времени безусловного укрепления французской абсолютной монархии, совсем не предполагает исторического ракурса, если подразумевать под последним традиционную установку на «объективную» фактографичность. Если исторический аспект и должен присутствовать как необходимое восполняющее звено, позволяющее уточнить процессуальность литературных и - шире - культурных явлений, то главным образом как ценностно-смысловая парадигма, устанавливаемая в текстах эпохи и определяющая осознанные (в том числе оправданные совокупностью условий) установки времени на воплощение предполагаемых как жизнеспособные условно-символических моделей (такой подход используется в целом ряде современных исторических трудов, например, в работах М. Ферро, который, в частности, прослеживая «переход к государству-королю» в XVII в., выстраивает концепцию с опорой на идеологически значимые тексты, среди которых и «Политическое завещание» Ришелье, где устанавливается принцип сакрализации монарха, а также обосновывается понятие «разумности» как абсолютности государственного интереса [I]). Такого рода историзм как прояснение функционирования семиотического пространства в его национальной специфике предполагает вопрос изменчивости, которая может быть объяснена в анализе природы «власти» как наиболее активно проявляющегося силового механизма. Продуктивной с точки зрения приложения к разной природе - материальной, как и ментальной (здесь филологической как реализованной в литературных и критико-теоретических текстах), социальных явлений в их подвижности представляется концепция власти М. Фуко, согласно которой власть есть обусловленная многочисленными 
факторами, всегда трансформирующаяся система взаимовлияния контактирующих сил, наблюдаемая на всех уровнях общества, при этом ключевой оказывается проблема «субъекта» в его обязательном самопроявлении. Исключая прочее, для нас важно, что «субъект», взятый во взаимодействии с властью, может быть рассмотрен как «субъект говорящий», т. е. участвующий в организации смысловых отношений, прояснить которые в данном случае помогает литература и критика, транслирующие, словами М. Фуко, «тип реальности», с которой мы имеем дело и которая во многом задает принцип концептуализации изучаемого материала в кодово-языковом выражении. М. Фуко говорит о невозможности существования «власти» без «свободы», которые находятся в отношениях взаимного провоцирования: «...если в основе функционирования власти и в качестве устойчивого условия ее существования есть “неподчинение” и всегда в сущности непокорные силы высвобождения, нет системы власти без сопротивления, без ускользания или уклонений, без возможных переворотов; всякая власть заключает в себе, по крайней мере потенциально, стратегию борьбы» [Іо, с. 236]. Такого характера неоднозначную связь, предполагающую постоянное видоизменение при условии взаимного влияния разных сил, целесообразно перенести на культурную эпоху, чьи особенности проявляются в законах функционирования текста, подвижного по причине внутреннего противодействия в его границах сближающихся и расходящихся знаков / смыслов. Активность говорящего субъекта, испытывающего идеологическое воздействие, соглашающегося с ним и одновременно ему противодействующего, сходна с бартовской идеей «литературы», которая есть «спасительное плутовство, уклонение, прекрасная уловка, которая позволяет услышать живой язык за пределом власти» [4, с. І6].

И здесь встает следующий вопрос, можно ли считать классицизм «литературой» в подобном современном смысле слова или же он исчерпывается риторикой как жесткой, законсервированной языковой структурой или стилем как соответствием eloqutio совершенному «вкусу». В последнее время наметилась устойчивая тенденция расшатывания канонического образа классицизма. Так, Л.Ф. Норман, выступая против «идеализированного», «нормативного» классицизма, говорит о «неклассическом классицизме», имея в виду под этим продолжительный период, когда правила еще не были установлены и отношения между авторами и публикой не были 
устойчивыми [II, с. 355]. С. Кут в статье «Риторика в XVII веке: спорное господство» констатирует видоизменение риторики, ослабление ее позиций под воздействием многочисленных факторов, таких, как развитие науки и философии, постепенное укрепление у авторов убежденности в их независимости от образцов, изменение представлений о стиле под влиянием развития концепта «возвышенное», в соответствии с которым распространялась идея «устремленности самого оратора, оправдывающей выражение сугубо индивидуальной манеры», а также влияние на аксиологические и стилистические критерии салонной культуры с ее установкой на отход от публичного красноречия к частному («...риторика вездесуща, но на протяжении века ее империя разрушается» [8, с. II3]). Э. Бури указывает на проблему появления во Франции XVII в. «писателя», которого необходимо понимать «в связи с политическими и социальными смыслами, которые сопровождают формирование государства в его современном виде» [5, с. 34]. Если допустить активность автора, осуществляющего свой контроль над литературным творчеством и устанавливающего себя через него в роли активного участника государственного устроительства, то будет очевидно, что риторика, узурпированная властью, которая есть «прежде всего символическое господство, семиотическое влияние» [12, с. 284], становится одним из двигателей разворачивания художественного текста («...писатель стремится воспроизвести в нарративной форме столкновение между политическим авторитетом и “другой” властью, достоянием литературного слова» [І2, с. 289]). В этом случае стоит вспомнить посвященные драматургической поэтике пьес Корнеля работы Ж. Форестье, в которых убедительно показывается, как «политическое» в трагедиях становится собственно организацией драматической композиции, определяя конфликт и его развитие, а также характер трагедийного напряжения, иначе говоря, во всех трагедиях драматурга повторяется найденный принцип структурирования политического конфликта [9].

Как можно увидеть, проблема власти смыкается с проблемой классицизма как успешно функционирующей текстовой структуры. В настоящей статье нас интересует парадигма языкового мышления века классицизма во Франции, которая просматривается как в художественных, так и в критико-теоретических сочинениях. В изучении этой парадигмы целесообразно отталкиваться от следующего общего положения. Эпоха испытывает необ- 
ходимость в установлении надличного Авторитета, каковым может выступать христианская вера, институт государства, королевская власть, культурная традиция, Античность, язык и т. п. Однако если этот Авторитет получает предельное распространение и усиление, т. е. если он абсолютен, не остается места для отдельного, оригинального. Отсюда складывается особого рода ситуация: устанавливая Авторитет, стараются от него ускользнуть, освободиться из-под его тотального влияния, однако не подрывая его основ и веры в него, поскольку этот надличный Авторитет является обязательным условием укрепления авторитета личного. В этом подчинении Авторитету и одновременно высвобождении из-под его давления и возникает напряжение, подрывающее жесткую стройность воспроизводимой знаково-смысловой структуры вплоть до приводящих к явным противоречиям ее неожиданных изломов. Если говорить о действии обозначенного механизма относительно власти, то обнаружение ее авторитарного характера происходит за счет опустошения ее знака, а следовательно, децентрализации социально-политических звеньев, вплоть до превращения монархических идей в антимонархические.

Итак, «власть» должна пониматься как в узком смысле (прежде всего политическом: абсолютная монархия во Франции XVII в., которая использовала театр для своего укрепления, в соответствии с чем на сцене представлялась мифологизированная картина иерархической системы, включающей, наряду с идеологическими, и этические смыслы), так и в широком (для этого используется концепт «Авторитет», который обозначает всякое понуждающее давление, проявляемое на уровне текста: теоретическая и художественная традиция Античности, отчасти присвоенная и навязываемая пишущему нарождающейся литературной критикой, императивный свод правил, жанровый стандарт, наконец, жесткая заданность рационализированного языка). В связи с этим «автор» понимается как пишущий, последовательно вырабатывающий собственные принципы драматического письма, проявляющий себя в тексте через фигуры отдельных персонажей и драматическую структуру в целом, интенционально действующий по принципу уступки Авторитету и одновременно сопротивления ему в утверждении креативной автономности. В таком ракурсе исследования случай Корнеля представляется уникальным: при жизни и в последующие эпохи он - признанный классик, т. е. «правильный драматург», чьи трагедии 
используются в качестве иллюстрации классицистической эпохи, и вместе с этим он - гениальный творец, успех и оригинальность манеры которого во многом заключаются именно в ускользании, нередко скрытом, но настойчивом позиционировании внутреннего несогласия с подавляющими политическими и эстетическими законами. В подобном аспекте театр может быть представлен как социально-политический феномен и как авторскими усилиями функционирующая и трансформирующаяся система, что, в свою очередь, позволяет пересмотреть подходы к определению классицизма как внутренне подвижной и неоднородной знаково-смысловой системы.

Для рассмотрения обозначенного вопроса, помимо трагедий Корнеля, целесообразно привлечь теоретические трактаты того времени, в которых были бы аккумулированы ценностно-мировоззренческие и художественно-поэтологические установки XVII в. Труд Франсуа Эделина (больше известного как аббат д` Обиньяк) «Практика театра», опубликованный в I657 г., стоит несколько особняком в ряду теоретических сочинений своего времени. Его нельзя рассматривать как только сведение положений, известных из более ранних поэтик, как это может показаться на первый взгляд. «Практика театра» представляет собой квинтэссенцию ожиданий эпохи от театрального зрелища, которое воспринималось как сверхреальность, в создании которой принимали участие как литературные круги (теоретики и драматурги) и общество (образованная верхушка и народ), так и власть в ее стремлении к усиливающим ее влияние преобразованиям. «Практика театра» выражает общую закономерность: в XVII в. театр становится исторически и политически востребованными отношениями между драматургом (теоретиком) и зрителем, упорядоченными в рамках развивающейся в государстве системы соподчинительного взаимодействия и отчасти контролируемыми режимом. Драма рассматривается д` Обиньяком не как сочинительство как таковое, но как особого характера зрелище: безупречно организованное утопическое действо, участвующее в преображении государства как целостности. В его практическом применении театр есть упорядоченное построение интеллектуально и эмоционально воздействующих сцен, в которых автор как мыслитель и организатор происходящего на сцене, актеры, превратившиеся в персонажей, и зрители как заинтересованные свидетели соприсутствуют, т. е. между ними устанавливаются определенного рода отношения. В его теоретическом преломлении театр есть гипотетическая кон- 
струкция как образец функционирования универсальных связей. Учитывая эти два аспекта, д` Обиньяк прежде всего задается целью установить театр как объект письма в пространстве и времени. В сочинении д` Обиньяка театр представлен как вершина тотальной культурной общности: в отличие от других видов искусств, он является идеальным способом безграничного расширения влияния (как на разные социальные слои, так и на разные народы). Такое исключительное положение театра делает его знаком авторитетности власти и одновременно средством ее укрепления. Власть как бы отражается в театре, находит в нем свой совершенный образ, как и модель устанавливаемого ей порядка («..правители не могут сделать ничего лучшего для их славы и блага их подданных, чем установить и поддерживать публичные зрелища и игры в превосходном порядке и с великолепием, достойным их короны» [3, с. 9]). Театр прямо участвует в управлении народом, поскольку он является самым действенным инструментом влияния, посредством театра власть предельно возможно себя распространяет, обеспечивает абсолютный контроль, так как в этом совершенном - насильственном (поскольку это спрограммированное воздействие) и одновременно приятном (поскольку это все же развлечение) - действе представители власти и подданные нераздельны, как бы действуют сообща («К тому же эти великие политики имеют обычай украшать их правление публичными увеселениями и устраивать так, чтобы их самые славные дела служили только средством или предлогом для того, чтобы дать народу, которым они управляют, все возможные развлечения» [3, с. 2г]). Пространственная ориентация театра как господствующей над всеми другими социальной надстройки, установление которой в ее гарантируемом совершенством формы превосходстве и фиксируется д` Обиньяком, препятствует его временной подвижности (не будем забывать, что эпоха тяготела к остановленному, закрепленному в пространстве - по принципу живописного полотна - образу).

Время, отражаемое в труде д` Обиньяка, - современность (а конкретнее I640 г., к которому относят написание большей части текста), это период безусловного торжества театра, совпадающий с неопровержимым могуществом режима Ришелье. Согласно д` Обиньяку, развитие драматического искусства напрямую зависит от воплощающейся в совершенную государственность воли мудрого властителя. Без государственной системы, построенной на безусловно рациональных основаниях, не может быть 
театра. Правление Ришелье совпадает, активизируя этот процесс, с небывалым дотоле расцветом драмы, который при иных режимах уже не будет повторен: при кардинале театр достиг своей вершины, к которой должны будут стремиться следующие поколения («Благодаря его (Ришелье. - Л.С.) щедротам она (сцена. - Л.С.) получила новые силы и начала возвращать себе свои древние права, свою первую красоту, свое благородство и свой блеск» [3, с. I6]). Само правление Ришелье - этого «великого человека», явившего собой «целую эпоху великих и прогрессивных вещей» [3, с. I7], организуемое по принципу театра, представляло собой совершенное зрелище («Блеск и величие зрелищ лучше всего может происходить только от того, кто сам являет собой самое блистательное и самое великое зрелище в мире» [3, с. I7]). Согласно рассуждениям д` Обиньяка, все, кто хоть сколько-нибудь причастен театру, обладают влиятельностью Авторитета. В аспекте проблемы отношения системы и личности такое воздействие можно определить как насилие, однако в мировоззренческой картине эпохи это понимается как благотворное влияние, «воспитание», научение, поскольку человек оценивается в его совпадении (или несовпадении) с принятым эпохой эталоном правильности представлений, вкусов (в том числе и эстетических предпочтений) и поведения: естественное в человеке видится как слабое, ущербное, как недоразвившееся, а следовательно, требующее вмешательства с целью восполнения изначального несовершенства.

Во Франции XVII в. идеологема власти находит подкрепление и в нарождающейся литературной критике, которая стремится присвоить себе неопровержимый авторитет судьи, своеобразного ментора, оспаривая таким образом право автора на его драматический текст. Примером чему может служить Жан Шаплен, перу которого, помимо прочих критических работ, принадлежат «Письмо о правиле двадцати четырех часов» и «Мнения Французской академии о трагикомедии “Сид” [6]. Согласно Шаплену, публично представляемое произведение есть встреча двух активных в своем взаимодействии инстанций - автора и общества. Автор представляет свое сочинение публике в надежде на его признание, публика (от лица которой и высказывается критик) обязательно его оценивает, выносит о нем определенное суждение. Шаплен указывает на заинтересованность автора в одобрительном приеме его текстов, а значит, в критике как выразителе компетентного мнения, всегда справедливого в своем приговоре об истин- 
ном и ложном в искусстве. Шаплен мыслит, что суждение критика абсолютно верно, исходя из точных критериев оценки, в соответствии с которой всякая сторона произведения определяется как достойная одобрения или порицания.

Поскольку Абсолют, к которому апеллирует классицизм, a priori не может быть совершенным в большей или меньшей степени, проблемно-неопределенным, у Шаплена речь идет об иной эстетической модели как цели всякого творческого акта. Эта модель изменчива, установлена не в полной мере, ее всегда можно дополнять и совершенствовать. Шаплен утверждает взаимозависимость драматурга и критика, которые оба участвуют в установлении идеального образца драмы. Творчество драматурга дает материал критику для того, чтобы тот мог на новом этапе, уточнив и дополнив характеристики, определить лежащие в основе того или иного жанра принципы. Критик, в свою очередь указывая на достоинства и недостатки, направляет развитие автора, проясняя ему те обязательные признаки, на соблюдение которых должны быть направлены его усилия. В этом взаимодействии критика и драматурга, которое провоцирует развитие жанра, согласно Шаплену, ведущая роль принадлежит критику. Критик стоит выше автора, поскольку в своем теоретизировании он увереннее движется к Абсолюту. Построенная по законам разума и в строгом соответствии с этическими принципами, лишенная всяких противоречий, а потому неподвижная, ограниченная правилами система, которая была бы точной иллюстрацией теоретического сочинения по драме, - вот проповедуемый Шапленом идеал, который и есть предел всякой критики и который он принципиально настойчиво навязывает автору (в том числе и Корнелю). Если принимать во внимание театральную практику с ее необходимостью развития, возникает требующая прояснения проблема: в какой мере теория классицистического театра способна видоизменяться, приводя правила и нормы в соответствие с жанрообразующими принципами драмы и учитывая происходящую в современности модификацию трагедии и комедии, наконец, в какой мере теоретические посылы условны для самой драматургической практики. Ответив на эти вопросы, можно понять, что в XVII в. обеспечило живучесть и, более того, подвижность драматургических жанров.

Для того чтобы проследить, каков принцип активности в этой ситуации идеологического и вместе с этим теоретико-эстетического давления 
драматического автора, обратимся к трагедии Корнеля «Гораций». «Гораций», написанный больше чем через три года после «Сида» (для Корнеля перерыв довольно значительный, если учитывать, что в период с I640-го по I65I-й не проходило и года без того, чтобы не появлялось новое сочинение драматурга в трагедийном жанре), является самой безупречной с точки зрения классицистических правил трагедией. Как принято считать, Корнель учел главные замечания своих оппонентов: обратился к сюжету из античной истории, отказался от любовной темы ради героической, строго выдержал закон трех единств, не допустил нарушения единообразия поэтической формы, наконец, полностью подчинил главного героя долгу («образцовость» этой трагедии, т. е. ее соответствие вырабатываемым классицизмом эстетическим нормам, подробно рассмотрена Т.Г. Чесноковой в статье «Поэтика “римской доблести” в трагедии Корнеля “Гораций” [2]). Безусловно, с «Горацием» Корнель выйдет к политической проблематике, которую будет разрабатывать на протяжении всего последующего творчества, а также найдет ту меру величия характера и поступка, которая навсегда останется одним из ориентиров его драматического письма, а следовательно, переход от «неправильного» «Сида» к «правильному» «Горацию» в движении автора вполне закономерен. Однако не лишним будет поставить вопрос о том, насколько Корнель подчинился заданным временем требованиям эстетического образца («Гораций» был одной из самых популярных трагедий при Людовике XIV он ставился на сцене I45 ра3) и насколько стремление к константным поэтологическим величинам для него как исключительного, а значит, прежде всего самостоятельного, творца было органично. Инициируемое сознанием неизбежности должного совпадение с предзаданной нормой чревато зависимостью, остановкой, окостенением. Гений Корнеля был слишком чувствительным к опасности подавления его силой Авторитета, что позволяло ему избежать ловушки санкционированных господствующей идеологией власти образцовых иерархических смысловых схем, которые он, казалось бы, сам закреплял.

Корнель как бы выражает полную готовность подчиниться уже довольно прочным, неопровержимым законам политического / поэтологического контекста. Все издания «Горация» до І656 г. сопровождались посвящением кардиналу Ришелье, сама грандиозная фигура которого соответствует колоссальным размерам славного римлянина. Это срастание образов про- 
исходит через сближение, наложение схожих, настойчиво повторяющихся, довлеющих себе значений: «благородный римлянин», «самая высокая тема во всей Античности», «достоинство предмета», «следствие великих идей». Какое же место в этих плотно спаянных, неколебимо жестких, герметичных смыслах отводится автору? Он располагается на почтительной дистанции от все затмевающего, заполняющего собой все пространство текста всемогущего объекта восхваления (как, собственно говоря, и положено в посвящении), в данном случае важно само его движение к этому Авторитету (которому он может стремиться подражать, у которого может учиться, с которым в конечном итоге может соединиться) или его отступление от него, т. е. ускользание, страхующее застывание, предусмотрительная автономизация. Корнель как автор посвящения использует второй вариант: он не спешит навстречу тому, что его значительно превосходит, близкий контакт с чем может обернуться зависимостью («...молчание, в котором до настоящего времени меня удерживало уважение...» [7, с. 2Іг]). Корнель и заодно с Ришелье (например, он говорит об удачном выборе сюжета, который не может не понравиться кардиналу: «...у меня есть одно преимущество: нельзя осудить (что было бы несправедливостью) мой выбор»; «...тема может приобрести еще больше достоинств, если разработана искусной рукой»; «...это заметное изменение, которое отмечают в моих произведениях... есть следствие великих идей, которые оно (Ваше Преосвященство. - Л.С.) мне внушает»; «...мы (авторы, пишущие для театра. - Л.С.) обязаны Вам двумя очень важными вещами: во-первых, высокой целью искусства; во-вторых, легкостью ее познания <...> чтобы ими овладеть, мы не нуждаемся больше в других уроках, чем обратить наши взгляды к Вашему Преосвященству» [7, с. 2II-2I2]), и как бы сам по себе («...замешательство, которое свойственно всем, кто пишет»; «...в моем исполнении она (тема. - Л.С.) по крайней мере получила все те достоинства, которые <...> оправданно было бы ожидать от провинциальной музы, которая <...> ведома не столь ярким светом, как те музы, которые им постоянно освещены»; «...и чем еще можно объяснить то, что к ним (сочинениям. - Л.С.) примешиваются недостатки, как не поверхностными знаниями, к которым я возвращаюсь, когда остаюсь предоставлен моей собственной незначительности» [7, с. 2II-2I2]). Тот же принцип письма относительно автора наблюдается и в «Горации». Возвышающаяся, заслоняющая собой всех других персонажей, расширяющая 
свое безусловное влияние на текст фигура Горация при всем ее доминирующем положении не поглощает собой всего пространства трагедии. Необходимо выяснить, что скрывается за навязывающей себя очевидностью авторитетных смыслов, которые поддерживают фигуру Горация, укрепляя ее настолько, что она становится практически неуязвимой, иначе говоря, необходимо обнаружить, какие значения ему противодействуют.

Отправной точкой может служить отрывок из диалога двух главных героев - Горация и Сабины. Гораций: «Это тебе нужно возвышать свои чувства до моих, а не мне опускаться до стыда твоих». - Сабина: «Для подражания себе ищи души более совершенные» [7, с. 264]. Корнель как автор - неисчерпаемая, самовоспроизводящаяся риторическая система - не может быть весь с его активизирующими смыслами представлен в образе Горация, для него он слишком ограничен, инертен. Необходим дискурсивно более гибкий герой, способный заключать в себя самые разные - вплоть до противоположных, находящихся между собой в отношении спора - позиции, не останавливаясь ни на одной из них, т. е. не сужаясь, сворачиваясь, но разрастаясь так, что окончательный итог - остановка как разрешение идейного конфликта - в принципе невозможен. Таким персонажем является Сабина (о ее особом положении в трагедии говорит и то, что именно с ее монолога начинается драматическое действие и ее голос отчетливо, в достаточно развернутой реплике, звучит в заключительной сцене). Трагедия подчинения индивидуального Авторитетом не могла начаться с неподвижной точки - неопровержимого утверждения сверхличного смысла. Корнель заходит с противоположного конца: дает выговориться страдающей в своем, скрытом героине, обнаруживая такие значения сомнительного, уязвимого, предосудительного, которые противоречат официально признанному, должному, образуя тем самым заметное смысловое напряжение.

«Римское» в Сабине - это не ее собственное, принадлежащее ей от рождения, но то, что накладывает на нее замужество, то, что она осознанно принимает как закон, с которым должна совпасть («Я римлянка... потому что Гораций римлянин; я получила от него это определение, получив его руку...» [7, с. 2І9]). Сабина не родилась римлянкой, т. е. Авторитет ей не органичен, он не воспитывался в ней с детства, чувства к нему не укоренены в ее натуре, не через него она училась видеть мир и ощущать радость жизни (по словам Сабины, она увидела свет не в Риме, а в Альбе, и не Рим, но Альба была 
ее «первой любовью» [7, с. 219]). Это делает положение Сабины исключительным: всеми другими персонажами Авторитет получен от рождения, это судьбоносная данность, от которой они не могут отказаться и которую не могут поставить под сомнение, что было бы равнозначно преступлению (случай Камиллы). Итак, Сабине, в отличие от других персонажей, задана свобода отношения к Авторитету: она может располагаться на определенном расстоянии от него, оценивать его со стороны, относиться к нему как к чему-то внешнему, ей не принадлежащему, или приближать к себе, присваивать его в стремлении совпадать с ним. Именно Сабина чувствует опасность бессознательного приятия Авторитета, его насильственного давления в ситуации несовпадения этого обязательного закона с естественной предрасположенностью, неотчуждаемой требовательностью внутренних жизненно важных основ. В первых же ее монологах-признаниях Сабина утверждает, что не может отказаться от своего происхождения, исторгнуть из себя свое прошлое - она чувствует и помнит / осознает себя уроженкой Альбы, и в этом утаиваемом и оберегаемом она не принадлежит Риму. Если бы она как альбианка (т. е. все то в ней, что роднит ее со своей землей и семьей, все, что существует в ней «для себя» и в ситуации войны Рима и Альбы «про себя») была бы задавлена, ее связь с Авторитетом (Римом) превратилась бы в унизительную зависимость, рабство (по выражению героини, брак обратил бы ее в «закованную цепью рабыню» [7, с. 2І9]). То есть с самого начала трагедии посредством Сабины Корнель задает ситуацию, при которой Авторитет неабсолютен, более того, его безапелляционное приятие угрожает сохранению «я», которое нуждается в страхующей дистанции от того сверхсмысла, который может его поглотить. И Сабина сохраняет себя, настаивая на своем праве быть альбианкой, т. е. по существу быть самой собой.

Но далее нужно задаться вопросом: какой ценой это достигается? Сабина прямо признается, что не хочет победы Рима, боится его триумфа. В контексте всей трагедии и относительно позиции Горация это означает отступничество, предательство (на это указывает сама Сабина: «Если ты, Рим, думаешь, что это значит предавать тебя...» [7, с. 219]). «Если ты, Рим, думаешь» - это сигнал того, что появляется внешняя относительно говорящего точка зрения. Это официальная позиция Рима, который утверждает свое господство (такова его историческая миссия, которую никто не может ограничить). Этот безличный Рим-государство допускается Сабиной, но 
до конца не принимается ей, героиня продолжает противопоставлять себя этой безостановочно разрастающейся и совсем не считающейся с ней силе. Вот каков в характеристиках Сабины «безличный» великий Рим: «государство, которое еще при своем зарождении не смогло бы укрепить свою мощь без войны», Рим «должен возрастать», «его великая судьба не ограничит его римским народом», богами ему обещано «господство над землей», «благородное горение, которое... ведет к величию» [7, с. 219]. Такой Рим не допускает ее саму, не считается с ее существованием, иначе говоря, с позиции такого Рима Сабины просто нет. Героиня решается осуждать такой не знающий никаких сдерживающих мотивов Рим. «Неблагодарный, вспомни», - Сабина указывает ему на его связь с Альбой, и следующие за этим высказывания служат косвенным подтверждением того, что для Рима не существует памяти, вообще никаких ослабляющих его устойчивость факторов - оправдывающих или осуждающих, одним словом, его позиция не допускает никакой субъективности. Итак, в первых же монологах Сабины Корнель определяет безличный Авторитет и одновременно располагающуюся от него на заметном удалении единичность, которая утверждает свое право быть собой именно в отделении себя от поглощающей закономерности должного. Вместе с тем важно, что в этом выделении Сабиной себя из Рима, которое в акцентировке личностных интересов допускает даже критику государства, нет прямого противостояния, открытого бунта. «Я совсем не хочу восставать против этого благородного горения, которое <...> ведет к величию» [7, с. 219], - делает оговорку Сабина. Отсюда следует, что отношения Сабины (Корнеля!) с Авторитетом гораздо сложнее: Авторитет отстраняется, критикуется и вместе с этим не отвергается, допускается как обращенное к единичности закономерное требование подчинения.

В следующем же монологе Сабины задается ситуация возможного совпадения с Авторитетом. Для этого потенциального совпадения с Авторитетом необходимо несколько условий. Во-первых, должна измениться точка зрения на Авторитет: личность должна в каких-то оценках отчасти присвоить себе Авторитет, сделать его в какой-то степени «своим». Так, в дискурсе Сабины происходит резкое переключение: с подачи собеседницы, римской матроны Юлии, она начинает говорить о Риме не как о государстве, которое укрепляет свое могущество, непомерно разрастается, устанавливая свое господство над другими землями, а как о городе, к которому 
принадлежит ее муж и которому он служит, не отделяя славы родины от своей жизни. Во-вторых, личность должна признать справедливым необходимое требование к себе, что должно подкрепляться надеждой согласовать с Авторитетом свои частные интересы (Сабина говорит о том, что долгое время жила надеждой на примирение между двумя городами). В-третьих, потенциальное совпадение с Авторитетом (в случае с Сабиной / Корнелем никогда не предполагаемое как полное и окончательное) всегда требует от обособленного «я» некоторого самопринуждения: Сабина, подавляя привязанность к Альбе, делала над собой усилия «быть во всем римлянкой» [7, с. 220] (героиня осуждала в себе ревность к победам Рима, его славе, т. е. вытесняла в себе отношение к Риму как к противнику своего родного города). Однако дискурс Сабины разворачивается в движении к Авторитету (при соблюдении всех вышеперечисленных условий) - и тут же от него: в обостряющемся противостоянии городов она не может согласиться с распространяющейся на все силой Рима (героиня признается, что не может «быть во всем римлянкой»: это предполагаемое самоотречение превосходит ее возможности). Более того, разбираемый монолог заканчивается заявлением Сабины о своем праве вообще отречься от Авторитета, вступить с ним в открытый конфликт (героиня говорит о том, что будет ненавидеть Рим в том случае, если он окажется победителем). Таким образом, Корнель оставляет возможность разрыва с Авторитетом, ухода от него в том случае, когда он становится насилием, несет угрозу полного подавления личностного.

В дискурсе Сабины можно наблюдать схождение крайностей, которые в их пересечении создают видимость снятия идейного конфликта. Подчеркнем, что Сабина первая (еще до Камиллы) решается бросить вызов Авторитету, однако, что принципиально важно, не опровергая его, не подрывая к нему доверия. Это происходит в ее обращении к Горацию и Куриацию перед их поединком. Ее высказывание начинается с ответа на встревоженный вопрос Куриация: после разговора с Камиллой он предполагает, что его сестра, так же как и его невеста, будет со слезами просить его отказаться от боя с Горацием. Сабина спешит разубедить его в этом, и действительно, ее речь строится на иных логических основаниях. Сабина прекрасно видит, насколько неколебима верность долгу ее мужа и брата, понимает всю бессмысленность каких-либо ее опровержений, она чувствует (а скорее всего, 
об этом знает Корнель, выстраивающий неопровержимую цепь аргументации, в которой учитываются взгляды всех героев), что, как только попытается открыто выступить против Авторитета, будет тут же разбита жесткостью безапелляционных провозглашений сверхличного закона (вспомним, что Сабина осознанно принимает для себя требовательный императив «Рима» и «римского»). Героиня идет по иному пути: она уверенно настаивает на необходимости боя между Горацием и Куриацием. Сабина указывает на все те значимые ориентиры, к которым ранее прибегали мужчины (заметим, что это совершенно иная тактика убеждения оппонентов, нежели у Камиллы): данное от рождения благородство («...ваша кровь слишком благородна» [7, c. 237]), «твердость великих натур», «честь», которая всегда должна быть «безупречной», любой поступок должен быть «достоин» славных героев. Сабина утверждает, что, если бы к намерениям Горация и Куриация примешалось что-нибудь низкое, она бы первая это осудила. Такой убедительной защите гражданского долга никто из слушающих возразить не может.

По существу, Сабина встает здесь на позицию Горация и Куриация: в защите интересов родного города нужно идти до конца, не считаясь ни с какими затруднениями. Однако, согласно дальнейшему рассуждению Сабины, для поединка Горация с Куриацием, который должен был закончиться смертью одного из них, есть одно серьезное препятствие, которое может бросить тень на их честь, - они связаны родством, и эта связь скреплена ей, а это значит, что главным препятствием их сражения является она. Сабина предлагает Горацию и Куриацию убить ее, и подобная логика высказывания оказывается наиболее последовательным утверждением абсолютности Авторитета: если Рим и Альба требуют битвы, ее участники, убивая своих противников, должны их ненавидеть, смотреть на них только как на врагов. «Разбейте ваш союз, порвите скрепляющую его цепь; и поскольку ваша честь требует ненависти, купите моей смертью право друг друга ненавидеть: этого хочет Альба и Рим, нужно им подчиниться» [7, с. 238]. В этой фразе Сабины нет ничего больше того, на чем уже настаивал Гораций: при сложившихся обстоятельствах закон подчинения требованиям государства диктует, чтобы все личное было отброшено как препятствие. И Гораций молчит: он не может ничего возразить Сабине, которая выражает его собственные убеждения. Логика высказывания неопровержимо проста: нужно переступать через все и в данном случае нужно переступить через 
Сабину. Гораций вынужден отступить! Монолог Сабины - провокация Корнеля, подрывающая доверие к абсолютности Авторитета, подчеркивающая невозможность полного совпадения с ним. Получается, что Сабина разбивает позицию Горация (что не удается ни одному другому персонажу). Обособленное личное (согласно корнелевской риторике «человеческое») не может быть никогда до конца отброшено, в этом своеобразная страховка логики драматического действия и одновременно страховка корнелевского языка: в неустранимости внутреннего «я», в любых ситуациях сопротивляющегося растворению во внешнем, обезличиванию, окаменению в памятнике ценой отказа от длящегося существования с его вдумыванием и вчувствованием, - гарантия подвижности и богатства трагедийной риторики (и, позволим себе предположить, страховка европейской культуры, которая в XX в. должна была отвечать на многие вопросы истории: насколько тоталитарная идеология, используя многочисленные лозунги служения государству, могла подчинить себе личность, заставляя переступать через человеческое в фанатизме веры в долг верности сверхличным интересам). «Начните же с Сабины делать из ваших жизней достойную жертву вашим дорогим отчизнам» [7, с. 239], - призывает героиня Горация и Куриация. Предлагаемое Сабиной ее убийство - это одновременно и самозаклание, и протест (пусть Авторитет торжествует, но тогда я не могу существовать). Риторика Сабины (за которой, безусловно, стоит Корнель как художник, отвоевывающий свою свободу от давления ограничивающего его Авторитета) оказывается настолько мощной, что Гораций растерян, испуган; с легкостью разбивающий любые, отличные от его собственных аргументы, он не может ничего возразить жене. «Что я тебе сделал, Сабина? > ... Что тебе сделала моя честь? И по какому праву со всей силой ты нападаешь на мое мужество. <..> По крайней мере люби своего мужа, чтобы не брать над ним верх» [7, с. 240]. В этих словах Горация можно видеть косвенное признание в том, что Сабина пошатнула его веру в безусловность Авторитета.

Сабина обвиняет Горация в той, согласно ее представлению, не имеющей оправдания жестокости, которую он проявил по отношению к сестре. Вопрос заключается в том, имеет ли ее слово решающий перевес над словом главного героя, в какой мере ее дискурсивная позиция сильнее в прямом столкновении с позицией Горация. Спор Сабины и Горация после убийства им Камиллы можно считать кульминацией в конфликтном разворачивании 
текста трагедии. Согласно драматическому замыслу Корнеля, Гораций в его казни сестры дошел до предела в демонстративном утверждении абсолютной преданности Риму, доказав, что способен пожертвовать всем. Дальше Гораций как будто бы пойти уже не может - пятый акт посвящен его оправданию. Тем значительнее в этом построении завершающее четвертый акт столкновение Сабины и Горация как итог противостояния разных отношений к Авторитету, относительно героев имеющий судьбоносное значение, а в контексте структурно-смыслового построения трагедии демонстрирующий гибкость риторической стратегии Корнеля, которая активизируется из некоего центра - Автора - и которая не укладывается в границы сюжета, более того, всегда их превосходит. Относительно развития сюжета спор Горация и Сабины не играет никакой роли, он мог быть выпущен без всякого ущерба для движения событийного действия, этот спор важен именно как обостренность идейного конфликта, сущностно до конца не разрешимого. Важно, что в этом дискурсивном столкновении, где герои предельно открыты друг другу, побеждает Сабина - Гораций в нерешительности, растерянности отступает. Обратим внимание на то, что герой не убивает свою жену, хотя она об этом просит его и открыто встает на позицию Камиллы: «Добавь к Камилле Сабину - к твоей сестре твою жену; у нас одно преступление, как и одно горе; я так же жалуюсь, как она, и так же оплакиваю моих братьев...» [7, с. 264]. Тем самым Корнель снова указывает, по какому принципу происходит разделение героев, что обусловливает их противостояние. Гораций продолжает настаивать на абсолютности Авторитета и полном подчинении ему: уже то, что сестра и жена скорбят о гибели Куриациев, представляется ему изменой, недопустимой слабостью - никто не имеет права на проявление чувств, если они расходятся с официальным требованием, любое отступление от нормы непростительно, более того, преступно. Выражение Сабиной горя безапелляционно осуждается Горацием, порицается в крайне резкой форме: «недостойная жалость», «постыдные чувства», «слабость», «позор» $[7$, с. 264]. По одним этим словам можно понять, сколь категорично высказывание Горация. Это проявление крайней нетерпимости, агрессивности по отношению к инакомыслию санкционировано все тем же Авторитетом: сила давления угрожающе-наступательного дискурса Горация в том, что он говорит с позиции некоего Закона («абсолютная власть», «незыблемый закон» [7, с. 264]). Дискурс Горация, скрепляемый в избытке 
присутствующими в тексте понятиями «доблесть», «честь», «слава», лишен гибкости, он не может черпать питающие аргументацию смыслы ни в чем, помимо культа Рима. И в данном случае этого оказывается катастрофически недостаточно - достойно противостоять Сабине, которая настаивает на своем праве существовать независимо от Авторитета, герой не может.

Подчеркнем, что, в отличие от Камиллы, Сабина не опровергает Авторитет, не подрывает его основ: в ее устах слова «благородные удары», «доблестный», а также все те же «долг», «доблесть», «лавры» свидетельствуют о том, что героиня признает правомочность сверхличного Закона, готова согласиться с ним, но только не в том, что затрагивает свободу ее чувств, запрещает ей то, что оправдано самой человеческой природой. «Я совсем не обвиняю тебя в моих утратах, в этом случае я лишь испытываю чувства, которые должна испытывать, и я скорее виню в этом судьбу, нежели твой долг; и все же я отказываюсь от римской чести, если, чтобы ее соблюдать, я должна быть бесчеловечной» [7, с. 264], - настаивает Сабина в разговоре с Горацием. Героиня ясно понимает, что значит долг и каково безусловное требование, которое он предъявляет человеку, однако она так же отчетливо сознает и то, что является неотъемлемым правом ее личностного достоинства, иначе говоря, гарантией ее морального самосохранения, тем, с утратой чего она не будет больше собой, что неизбежно должно закончиться смертью. Именно так нужно понимать бросаемый Сабиной вызов «отказываюсь от римской чести» - утверждение, которым Корнель окончательно устанавливает в тексте невозможность абсолютного соответствия Авторитету, что привело бы к самоупразднению мыслящего и чувствующего «я». Сабина / Корнель как возможное сопротивление насильственному давлению Авторитета, способ сохранения «я» предлагает разделять «публичное» и «личное», т. е. то, в чем человек доступен всеобщему взгляду и, следовательно, сторонней, официально принятой оценке, - и то, чем он существует в интимной жизни, оставляет для себя. «При всех будем участвовать в государственных торжествах, дома же будем оплакивать наши личные несчастья...» [7, с. 264]. Все общее нужно отделять от своего: есть «общее благо» - и «личное горе». Перед таким рассуждением Сабины Гораций отступает: создать более сложную риторическую модель, превосходящую, перекрывающую ту, которая принадлежит героине, Корнель не может. Монолог Сабины - это поражение Горация, доказательство 
уязвимости, несостоятельности его позиции. Здесь устами Сабины Корнель спорит со своим героем, опровергает авторитетность его суждений, побеждает его, сам как Автор - усилием своего драматического письма - выходит из-под власти Авторитета, освобождается от его давления. Горацию нечего противопоставить тому, что сказано Сабиной, его дискурс оказывается исчерпан: он бросает замечание о «великой власти» женщин, о том, что эти «слабые победители мощно утверждают свое господство» над такими благородными характерами, как его собственный, после чего сразу же покидает сцену. Заметим, что в театре, где царит риторика и состоятельность героя зависит в первую очередь от умения аргументированно доказывать свою позицию, это означает полный провал.

Для понимания драматического замысла Корнеля и характера его проявления в тексте как Автора чрезвычайно важен последний монолог Сабины: далеко не случайно голос этой героини звучит в заключительной сцене трагедии наряду с голосом старого Горация и царя Тулла, контрастно отличаясь от их утверждающего пафоса. Сабина просит у царя смерти, говоря о ней и как об искупительной жертве - самозаклании ради спасения мужа (она как жена, т. е. его половина, должна принять требование социального и божественного правосудия), и как единственном для нее выходе из поглотившего ее отчаяния - невозможности бесчувствия и примирения в себе долга сестры и долга жены («Какой ужас обнимать человека, меч которого пресек мой род! И какое кощунство ненавидеть супруга за то, что он хорошо служит своему народу, государству и Вам» $[7$, с. 272]). По существу, в этом длинном монологе героини Корнель в финале трагедии закрепляет идею невозможности согласования личного с Авторитетом (для Сабины на чем риторически и расставлены акценты в ее высказывании - полное совпадение с Римом осуществимо только в смерти, иначе говоря, торжество сверхличного Закона требует самоустранения отдельного «я»). Итак, на уровне сюжета происходит разрешение конфликта, тогда как на дискурсивно-риторическом обнаруживается его неразрешимость. Вместе с этим, как было показано, дискурсивная позиция Сабины, отстаивающей правду личного, оказывается сильнее дискурсивной позиции Горация, защищающего Авторитет. На уровне событийного действия - поведение Горация и его оправдание - Авторитет безусловен, но на уровне текста он не абсолютен: дискурсивно-риторическая структура показывает, насколько Авторитет 
подчиняет себе персонажей и каков потенциал их вместе взятых и каждого в отдельности сопротивления Ему. В этом последовательном утверждении Авторитета и одновременно последовательном же высвобождении из-под его давления (и то, и другое наиболее полно показано в дискурсе Сабины) и заключается секрет активности драматического письма Корнеля. Признание над собой власти Авторитета и одновременно сопротивление ее насилию - это позиция оппонентов Горация, которая наиболее полно представлена в языковом образе Сабины, что и дало нам основание говорить, что именно за этой героиней скрывается Корнель. Все вышесказанное позволяет утверждать, что «Гораций» есть трагедия Автора, пишущего свои сложные отношения с властью. 


\section{Список литературы}

I Ферро М. История Франции. М.: Весь мир, 2015. 832 с.

2 Чеснокова Т.Г. Поэтика «римской доблести» в трагедии Корнеля «Гораций» // Arbor mundi. 2009. № 15. C. 9-27.

3 Aubignac, François Hédelin, abbé d'. La Pratique du théâtre. P.: Champion, 200I. 768 p.

$4 \quad$ Barthes R. Leçon. P.: Le Seuil, I978.54 p.

5 Bury E. De quel «âge classique» est-il encore question dans les études dix-septiémistes en France? // Cahiers de l'Association international des études françaises. 2008. № 6o. P. 27-42.

6 Chapelain J. Opuscules critiques. Genève: Librairie Droz S.A., 2007. 496 p.

$7 \quad$ Corneille P. CEuvres choisies. P.: Hachette Livre - BNF, 20I8. 348 p.

$8 \quad$ Coute $S$. La rhétorique au XVII siècle: un règne contesté // Modèles linguistiques. 2008. № 58. P. III-I30.

9 Forestier G. Essai de génétique théâtrale: Corneille à l`CEuvre. Genève: Droz, 2004. $396 \mathrm{p}$.

Io Foucault M. Le sujet et le pouvoir // Foucault M. Dits et écrits (I954-I988). P.: Gallimard, I994. T. IV. P. 222-243.

II Norman L.F. Historiciser le sublime, ou le classicisme entre modernité et antiquité // Revue d histoire littéraire de la France. 2007. № 2. P. 347-357. et pouvoirs de la littérature. Montpellier: PULM. 200I. P. 28I-298. 


\section{References}

I Ferro M. Istoriia Frantsii [History of France]. Moscow, Ves` mir Publ., 20I5. 832 p. (In Russ.)

2 Chesnokova T.G. Poetika "rimskoi doblesti" v tragedii Kornelia "Goratsii" [Poetics of "Roman prowess" in the tragedy of Corneille Horace]. Arbor mundi, 2009, no I5, pp. 9-27. (In Russ.)

3 Aubignac, François Hédelin, abbé d`. La Pratique du théâtre. Paris, Champion, $200 \mathrm{.}$ 768 p. (In French)

$4 \quad$ Barthes R. Leçon. Paris, Le Seuil, I978. 54 p. (In French)

5 Bury E. De quel «âge classique» est-il encore question dans les études dix-septiémistes en France? Cahiers de l'Association international des études françaises, 2008, № 60, pp. 27-42. (In French)

6 Chapelain J. Opuscules critiques. Genève, Librairie Droz S.A., 2007. 496 p. (In French)

7 Corneille P. Euvres choisies. Paris, Hachette Livre - BNF, 20I8. 348 p. (In French)

8 Coute S. La rhétorique au XVII siècle: un règne contesté. Modèles linguistiques, 2008, № 58, pp. III-I3O. (In French)

9 Forestier G. Essai de génétique théâtrale: Corneille à l CEuvre. Genève, Droz, 2004. 396 p. (In French)

Io Foucault M. Le sujet et le pouvoir // Foucault M. Dits et écrits (I954-I988). T. IV. P., Gallimard, I994, pp. 222-243. (In French)

II Norman L.F. Historiciser le sublime, ou le classicisme entre modernité et antiquité. Revue d histoire littéraire de la France, 2007, № 2, pp. 347-357. (In French)

I2 Saminadayar-Perrin C. Rhétorique et pouvoir au miroir du récit. Écritures $d u$ pouvoir et pouvoirs de la littérature. Montpellier, PULM, 200I, pp. 28I-298. (In French) 